\title{
obituary
}

\section{Ralph A. Sawyer}

Ralph Al.ANSON SaWyer, physicist and science administrator, died on $5 \mathrm{Dec}$ ember 1978 at the age of 83 .

Born in New Hampshire, he graduated valedictorian of his class from Dartmouth College in 1915 and then went to the University of Chicago on a travelling fellowship as a Chamberlain Fellow from Dartmouth. At Chicago he became one of R. A. Millikan's students and, after a brief tour in the US Navy, he received a PhD degree in physics there in 1919. Soon afterward Ralph joined the staff of the physics department at the University of Michigan and, except for the years of World War II, he served the University as a prolific researcher, dedicated teacher and, later, as a gifted administrator until his retirement in 1964.

Before he was called back into active service by the. Navy in 1942 Ralph had published more than 50 papers in the field of spectroscopy. His interest in the spectra produced by energetic light sources, which began with his first publication at Chicago on the characteristics of a vacuum spark, continued into his earlier years at Michigan. Using a normal-incidence vacuum spectrograph of his own design, together with an improved hollowcathode light source, for the extreme ultraviolet, Ralph and his students analysed the first spark spectrum of a considerable number of elements.

In the mid-thirties he became interested in rapid quantitative spectrochemical analysis and together with H. B. Vincent he developed the techniques to the point where a technician could make 'on line' determinations of the composition of samples in the steel-making process fast enough to control the composition of the batch of metal being processed.

From 1942 to 1945 , on leave from the University, Sawyer served as Director of the Armor and Projectile Laboratory at the Naval Proving Ground at Dahlgren, Virginia. However, he still maintained an active interest in spectroscopy and managed to finish his book Experimental Spectroscopy which was published by Prentice-Hall in 1944 and then, in revised form, in 1951. A third, paperback, edition was published by Dover in 1963.

In 1946 Sawyer was appointed Civilian Director of Technical Operations for the series of atomic bomb tests at Bikini Atoll known as 'Opera- tion Crossroads'. In view of the fact that he was both a Naval officer and an eminent scientist of proven administrative ability this was an ideal choice. The successful completion of this mission marked the end of Ralph's active service to the Navy and he was awarded their Commendation Ribbon. Later (1951) he was promoted from the rank of Commander to that of Captain in the Naval Reserve.

While the Bikini tests were in progress Sawyer was notified of his appointment as Dean of the Graduate School at Michigan and in the fall returned to Ann Arbor to assume the position which he held until his retirement.

Ralph's talent for administration brought him additional responsibilities. $\mathrm{He}$ became the first director of the Michigan Memorial Phoenix project which was devoted to the study of the peaceful uses of atomic energy and then, in 1959, he was appointed to the newly-created post of Vice-President for Research at the University of Michigan. These were times of new and rapidly expanding Federal support of university research and Ralph was in large measure responsible for establishing the University of Michigan as one of the leaders in Federallysponsored research.

Amid all these activities Sawyer somehow found time for service to various off-campus organisations. $\mathrm{He}$ served a term as President of the Optical Society of America and, earlier, was an associate editor of their journal. In 1963 he was awarded the Frederic Ives medal by the Optical Society for 'distinguished work in optics'. Ralph was elected to the Governing Board of the American Institute of Physics in 1954 and served as its chairman from 1959 to 1971 . This was a period in which many hard decisions had to be made and Ralph was described by one of the board members as a 'benevolent but firm leader, deeply respected by all'. Upon his retirement from the chairmanship he was awarded the Karl Taylor Compton gold medal by the Institute for 'distinguished statesmanship in science'. Sawyer also served a term as President of the Association of Graduate Schools and was advisor to or member of: the National Research Council, the Goddard Space Flight Centre, the National Bureau of Standards, the International Commission on Optics, and three US Naval Laboratories.

It can truly be said of Ralph Sawyer that 'he lived a life of large usefulness' Those of us who knew him well will miss his warm friendship and the entire scientific community will mourn the loss of his leadership.

W. Wallace McCormick

\section{I. Blokhintsev}

DMitril IVANovich Blokhintsev, the founder of the Soviet nuclear power industry and a prominent theoretical physicist, died suddenly on 27 January 1979. Although 71 years old. he was still actively involved in teaching at Moscow State University-his own alma mater-and in his work as head of the Laboratory of Theoretical Physics at the Joint Nuclear Research Institute at Dubna.

Blokhintsev had formerly been director of the Dubna Institute. from its foundation in 1956, until his official retirement in 1965. It was here that, in 1964, he announced the synthesis of element number 104. The Dubna institute was one of the first major joint efforts of the socialist bloc-the Comecon countries, with the addition of China, North Korea, North Vietnam. and Albania. As Director of the Institute, Blokhintsev received a number of orders and medals from the countries involved, as well as election to several foreign Academies.

Soviet honours, too, were bestowed on him, including the title of Hero of Socialist Labour, the Order of Lenin (four times), the Order of the Red Banner of Labour, the Order of the October Revolution and the Lenin and Stalin (now State) prizes. Many of these awards, including the Lenin Prize, were associated not so much with his academic talents but with his expertise as an organiser of the Soviet Union's nuclear power programme. In 1954, he was in charge of the construction of the Soviet Union's first nuclear power station, a modest $5,000 \mathrm{~kW}$ 'semi-pilot' plant at Obninsk, which was to do much, in the following decade, towards the development of Obninsk as a scientific centre with a wide range of research institutes.

Nevertheless, Blokhintsev's achievements in pure physics did not go unnoticed at home. Indeed, in the official Pravda obituary. which was signed by numerous high-ranking officials, including Messrs Brezhnev and Kosygin. pride of place is given to these. In the words of this official appreciation 'he enriched world science by his fundamental works in the field of quantum 